\title{
Correction to: Outdoor Learning and Play
}

\author{
Liv Torunn Grindheim, Hanne Værum Sørensen, and Angela Rekers
}

\section{Correction to: \\ L. T. Grindheim et al. (eds.), Outdoor Learning and Play, International Perspectives on Early Childhood Education and Development 34, https://doi.org/10.1007/978-3-030-72595-2}

The book was inadvertently published with the "Acknowledgements" section excluded in the chapters.

The correction has been incorporated by including the "Acknowledgements" section in all the chapters. 